\title{
EFFICIENT REMOVAL OF METHYLENE BLUE FROM AQUEOUS SOLUTION BY ALMOND SHELL ACTIVATED CARBON: KINETICS AND EQUILIBRIUM STUDY
}

\author{
M. K. Rai, B.S. Giri*, R. S. Singh and B. N. Rai \\ Department of Chemical Engineering \& Technology, IIT (BHU), Varanasi, 221005 (U.P.) India \\ *E-mail: balendushekher23@gmail.com
}

\begin{abstract}
Almond shell wastes were used to prepare activated carbons with chemical activation by $\mathrm{H}_{3} \mathrm{PO}_{4}$, which were tested for the extraction of methylene blue dye from a synthetic liquid solution. The characteristics properties of prepared activated carbon like a functional group and morphological structure were characterized. The prepared activated carbon with a high surface area of $1250 \mathrm{~m}^{2} / \mathrm{g}$ could be proved as a good adsorbent for the treatment of methylene blue. The batch process was performed to determine the optimum operating parameters for the adsorption of methylene blue (MB). It was seen that the adsorption behaviour of MB was changed by changing the operating parameters like $\mathrm{pH}$ of the solution, running time of the experiment, the amount of ASAC dose and initial concentration of $\mathrm{MB}$. At an initial $\mathrm{pH}$ of 7, maximum adsorption (100\%) was found in running time of $240 \mathrm{~min}$ and a dose of $2 \mathrm{~g} / \mathrm{L}$. In this case, the Langmuir adsorption isotherm model described well in compression to other models and maximum MB absorption uptake $(334.40 \mathrm{mg} / \mathrm{g})$ was calculated at a temperature of $30{ }^{\circ} \mathrm{C}$. The kinetics of adsorption was calculated with different concentrations of $\mathrm{MB}$ and it was better represented by the pseudo secondorder model.
\end{abstract}

Keywords: Methylene Blue, Activated Carbon, Almond Shell, Isotherm, Adsorption

(C) RASĀYAN. All rights reserved

\section{INTRODUCTION}

The different type of dyes is utilized to color in industries like as the textile, paper, plastic, wood and food. The dyeing industries produce pollutants between 30,000 and 150,000 t into receiving water per year, which causes bad health effects on the aquatic animal as well as human due to the toxicity of these dyes. ${ }^{1}$ The nature of methylene blue (MB) dye is cationic and it is utilized in medical for staining and for coloring material in textile industries which produces dark-colored polluted water. This polluted water causes low penetration of sunlight due to coverage of receiving water and it harms the health of flora and fauna. ${ }^{2,3}$ Therefore before the discharge of this polluted water, it is a need to remediate for a healthy environment.

In early days the different methods have been employed for MB removal like as, electrolysis, membrane separation, coagulation and advanced oxidation. ${ }^{4-6}$ Due to high cost, these methods of removal are not used commercially and it also generates production of secondary pollutants after removal of MB. ${ }^{7,8} \mathrm{An}$ alternate method such as adsorption has great concern for MB remediation due to low cost and simple arrangement of installation. ${ }^{9}$ In recent years for adoption, activated carbons (ACs) are used as adsorbent materials which have the large active internal surface area and high adsorption capacity. The function group and also large numbers of pores makes these materials suitable for removal of MB and other dyes form industrial effluent. ${ }^{10,11}$ But commercial activated carbon is not cheap due to the high cost of precursor for making activated carbon. ${ }^{12}$ Thus, to overcome this problem several types of research have been reported for the use of renewable and low cost agricultural or industrial wastes precursors for the production of activated carbon. ${ }^{13}$ These raw materials include waste rice straw ${ }^{14}$, orange pee ${ }^{15}$, karanj $^{16}$, sugarcane bagasse ${ }^{17}$, leaves of pineapple ${ }^{18}$, walnut shells ${ }^{19}$, coconut shell ${ }^{9}$ and rice husk ${ }^{20}$. Other research is also executed for remediation of $\mathrm{MB}$ from polluted water by other economical and environment adjustable activated carbons prepared from different agriculture woody wastes materials. There is a few

Rasayan J. Chem., 13(2), 979-990(2020)

http://dx.doi.org/10.31788/RJC.2020.1325627

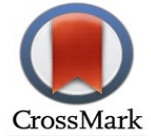


RASĀYAN J. Chem.

Vol. 13 | No. 2 |979 - 990| April - June | 2020

published information present on the almond shell for the manufacturing of activated carbon to MB adsorption from aqueous solution.

In the present study, the almond shell is used for the development of cost-effective and comparable to industrial activated carbon. Almond is a dry fruit that is produced in several countries of the world including India. The shell of almond is not used for making other materials and also no cost value. The almond shell is hard and having a high value of carbon content can be utilized as preparation of activated carbon. This almond shell wastes can be employed as a cost-effective and environment-friendly precursor for new activated carbon because these woody biomass has no use and disposed of as wastage. For this activated carbon, the almond shell was chemically activated with $\mathrm{H}_{3} \mathrm{PO}_{4}$. The prepared activated carbon was analyzed for remediation of MB dye in batch mode experiments by operating in different parameters. The prepared activated carbon is abbreviated as ASAC (almond shell activated carbon).

\section{EXPERIMENTAL}

\section{Adsorbate}

The different dye solution was made by Methylene Blue (Sigma -Aldrich, India) dye dissolved in double distilled water and this prepared solution was used as adsorbate in further experiments. The molecular mass of this $\mathrm{MB}$ dye is $373.9 \mathrm{~g} / \mathrm{mol}$ and chemically represented as $\left(\mathrm{C}_{16} \mathrm{H}_{18} \mathrm{~N}_{3} \mathrm{SCl} \cdot 3 \mathrm{H}_{2} \mathrm{O}\right)$. All other chemicals were commercially available with analytical grade.

\section{Preparation and Characterization of ASAC}

The almond shells were arranged locally nearby places. All dust particles of almond shells were cleaned with distilled water and kept for sun drying. After drying these raw materials were crashed in the form of different size powder ranging (14-72 mesh) with the help of disintegrator. The crushed powders (72 mesh size) were mixed with $\mathrm{H}_{3} \mathrm{PO}_{4}$. The ratio of these materials was kept as 3:1 (weighted mass of $\mathrm{H}_{3} \mathrm{PO}_{4}$ : mass of powdered shells, $\mathrm{w} / \mathrm{w}$ ) for chemical activation and this chemically impregnated mixture was kept for $24 \mathrm{~h}$ so that $\mathrm{H}_{3} \mathrm{PO}_{4}$ penetrates deeply into powder. For removal of moisture, the samples were placed in an oven for drying at a temperature of $70^{\circ} \mathrm{C}$ for the time of 10 hours after chemical activation. The dried chemically treated almond shell powder was carbonized at $700{ }^{\circ} \mathrm{C}$ for 2 hours in a muffle furnace (NSW India, NSW-101), heating rate $20{ }^{\circ} \mathrm{C}$ in presence of inert gas $\mathrm{N}_{2}\left(150 \mathrm{~m}^{3} / \mathrm{min}\right)$. After the carbonization of these samples were kept for cooling and then the samples were thoroughly washed with water so that it could reach at neutral $\mathrm{pH} 7$. After washing samples were dried in an oven at $60{ }^{\circ} \mathrm{C}$ temperature for the time of $24 \mathrm{~h}$. For storing the samples were kept into airtight bottles so that no moisture could come in contact. The physicochemical characterizations of almond shell activated carbon (ASAC) were carried out to know its chemical composition (CHNS content), functional groups, surface area and microstructure.

The various types of active functional groups which determines the activity of ASAC for MB uptake was revelled by using FT-IR investigation method (Scientific, Nicolet 5700) in the range of $500-4000-\mathrm{cm}^{-1}$. The surface structure and morphological characteristics of ASAC were analyzed by the Scanning Electron Microscope (FEI ${ }^{\mathrm{TM}}$, Quanta 200F) to determine the morphology and porous structure of the surface. The SEM results also provide information about the average pore size. The elemental analysis of ASAC was characterized by using an elemental analyzer (Euro-EA). The surface area which provides the available sites of adsorption of ASAC was determined using surface area analyzer (Micromeritics ASAP 2020). For this analysis the gas, $\mathrm{N}_{2}$ has adsorbed at a temperature of $-196{ }^{\circ} \mathrm{C}$ and then for the desorption process occurred at normal room temperature. The pore size and pore volume of ASAC also characterized by this surface analyzer. For the calculation of the point of zero charges (pHpzc), solutions having different $\mathrm{pH}$ ( 2 to 12) were prepared. Then, $0.15 \mathrm{~g}$ of ASAC was added to each sample and stirred for the duration of $24 \mathrm{~h}$. After that, the $\mathrm{pH}$ of the solutions at the final stage was investigated. A graph was drawn between the final $\mathrm{pH}$ and initial $\mathrm{pH}$ and $\mathrm{pHpzc}$ is the point where this curve intersects the line $\mathrm{pH}_{\mathrm{f}}=\mathrm{pH}_{\mathrm{i}}$.

\section{Batch Mode of Adsorption}

To carry out the removal efficiency the adsorption experiments were employed in conical flasks having $100 \mathrm{~mL}$ solution of different MB concentrations. Further to investigate the effects of different operating parameters, the experiments were conducted at a different condition such as running time (0-300 min), 
RASĀYAN J. Chem.

Vol. 13 | No. 2 |979 - 990| April - June | 2020

solution $\mathrm{pH}$ in the range of 2-12, ASAC dose $(0.20-1.0 \mathrm{~g} / 100 \mathrm{~mL})$, variable starting MB concentration range $(50 \mathrm{mg} / \mathrm{L}$ to $1000 \mathrm{mg} / \mathrm{L})$. The optimum values were obtained by this experiment. All investigations were performed at a fixed stirring speed of $180 \mathrm{rpm}$ and all batch experiments were performed in triplicate.

Equilibrium adsorption isotherm data were obtained by performing the experiments at $\mathrm{MB}$ concentration ranging from $50-1000 \mathrm{mg} / \mathrm{L}$, a dose of ASAC $0.20 \mathrm{~g} / 100 \mathrm{~mL}, \mathrm{pH} 7$ and $30^{\circ} \mathrm{C}$ temperature. A similar procedure was executed for analyzing the kinetics of $\mathrm{MB}$ adsorption at different concentrations of $\mathrm{MB}$ (100-300 mg/L) after consistent intervals of time. The remaining concentration of MB was calculated by measuring the absorbance of MB by UV-spectrophotometer (Elico, SL 159) at $665 \mathrm{~nm}$. The percentage adsorption of $\mathrm{MB}$ was calculated to form a difference in $\mathrm{MB}$ concentration before and after the adsorption. The uptake, $q_{e}(\mathrm{mg} / \mathrm{g})$ of $\mathrm{MB}$ on per gram of ASAC was evaluated using Eq.-1:

$$
q_{e}=\frac{\left(C_{0}-C_{e}\right) V}{W}
$$

Where the values of $C_{0}(\mathrm{mg} / \mathrm{L})$ and $C_{e}(\mathrm{mg} / \mathrm{L})$ represent the starting and equilibrium concentration of $\mathrm{MB}$ respectively, $V(\mathrm{~L})$ corresponds to the volume of MB solution, $W(\mathrm{~g})$ presents the mass of ASAC.

\section{Characterization of ASAC}

\section{RESULTS AND DISCUSSION}

FTIR spectra of adsorbent material from the almond shell at the initial stage and after MB uptake were recorded in the spectral range of $500-4000 \mathrm{~cm}^{-1}$ and presented in Fig.-1. The peaks observed at 2796 and $3900 \mathrm{~cm}^{-1}$ related to $\mathrm{O}-\mathrm{H}$ functional groups like as alcohols and carboxylic acids. ${ }^{21,22,9}$ The spectral peaks around $850-500 \mathrm{~cm}^{-1}$ confirms to $\mathrm{C}-\mathrm{H}$ and $\mathrm{CH}_{2}=\mathrm{CH}_{2}$ stretching groups. ${ }^{23,24}$ The band seen at 1748 and $1650 \mathrm{~cm}^{-1}$ could be represented to the $\mathrm{C}-\mathrm{O}$ and COO- stretching groups respectively vibrations in aromatic structures. ${ }^{25,26,18}$ FTIR spectra after adsorption on ASAC is indicated the shifted peak locations and low transmittance intensity at some bands due to MB attachment in pores of activated carbon.

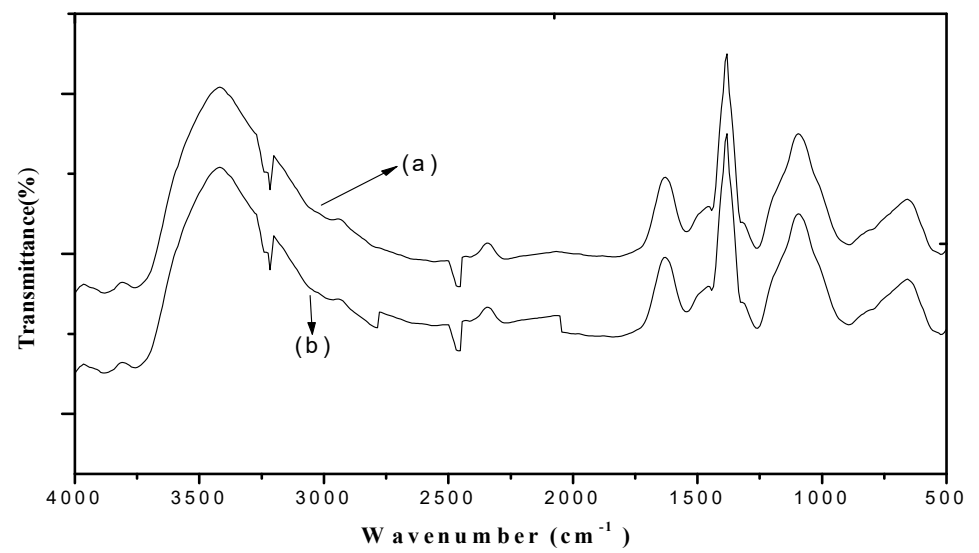

Fig.-1: FT-IR Spectra of Activated Carbon Before (a) and After Adsorption (b) of MB

The observed SEM images of ASAC are presented in Fig.-2. The role of $\mathrm{H}_{3} \mathrm{PO}_{4}$ to generate the porous structure of ASAC is observed on the surface. The appearance of porosity is due to dehydration which breaks the different bonds like $\mathrm{C}-\mathrm{C}$ and $\mathrm{C}-\mathrm{O}-\mathrm{C}$ of the almond shell during activation. The SEM image after MB adsorption shows that the pores are filled by $\mathrm{MB}$ adsorption on the surface and in the pores of activated carbon.

From the elemental analysis of almond shell (Table-1), it is seen that the higher percentage of carbon $(76.40 \%)$ in activated carbon. The same type of results was investigated by other activated carbon like hazelnut-husk (80.4\%) ${ }^{27}$ and sugar beet bagasse $(70-80 \%) .{ }^{28}$ The surface area of ASAC is found to be $1250 \mathrm{~m}^{2} / \mathrm{g}$ and pore volume is found to be $0.3885 \mathrm{~cm}^{3} / \mathrm{g}$. This result is compared with other activated 
RASĀYAN J. Chem.

Vol. 13 | No. 2 |979 - 990| April - June | 2020

carbons such as tapioca flour ${ }^{29}$ and orange peels ${ }^{30}$ having $986,618 \mathrm{~m}^{2} / \mathrm{g}$ BET surface areas and total pore volumes $0.57,0.39, \mathrm{~cm}^{3} / \mathrm{g}$ respectively. The physical characterization like average pore size and point of zero charges of ASAC was found to be $2.47 \mathrm{~nm}$ and 5.50 (Table-1) respectively which can take a role in adsorption capacity.

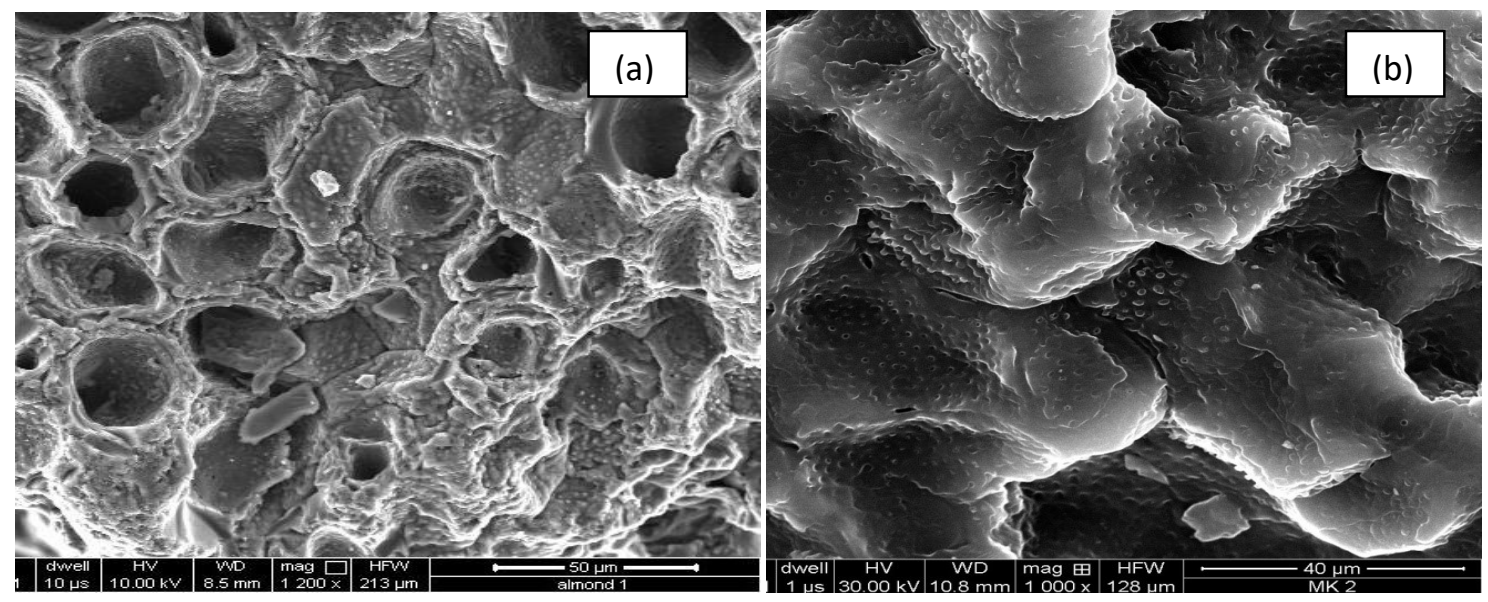

Fig.-2: SEM Image of Activated Carbon Before (a) and After Adsorption (b) of MB

Table-1: Physical Properties of Almond Shell Activated (ASAC) Carbon

\begin{tabular}{c|c}
\hline Parameters & Value \\
\hline BET Surface Area $\left(\mathrm{m}^{2} \mathrm{~g}^{-1}\right)$ & 1250 \\
\hline Pore Volume $\left(\mathrm{cm}^{3} \mathrm{~g}^{-1}\right)$ & 0.3885 \\
\hline Average Pore Size $(\mathrm{nm})$ & 2.47 \\
\hline $\begin{array}{c}\mathrm{pH} \text { at the point of Zero Surface } \\
\text { Charge }(\mathrm{pHpzc})\end{array}$ & 5.5 \\
\hline Elemental Analysis $(\%)$ & 76.40 \\
\hline $\mathrm{C}$ & 2.40 \\
\hline $\mathrm{H}$ & 1.38 \\
\hline $\mathrm{N}$ & 0 \\
\hline $\mathrm{S}$ & 19.82 \\
\hline $\mathrm{O}$ &
\end{tabular}

\section{Effect of Initial pH of MB}

The starting $\mathrm{pH}$ of any dye effluent is an adequate parameter to investigate the uptake capacity of any absorbent and it is also important to investigate the removal effect of activated carbon. ${ }^{31}$ The role of $\mathrm{pH}$ for MB uptake (Fig.-3) onto ASAC was performed at various solution $\mathrm{pH}$ ranges (2-11), 0.25/100 $\mathrm{mL}$ of ASAC dosage, initial concentration of dye as $100 \mathrm{mg} / \mathrm{L}$ and $30^{\circ} \mathrm{C}$ for $6 \mathrm{~h}$. The adsorption efficiency was less in acidic range ( $\mathrm{pH} 2$ to 6), but it was observed maximum under basic conditions above $\mathrm{pH} 7$. The reason for this behaviour is due to the basic nature of $\mathrm{MB}$ dye having positive ions in solution. ${ }^{32,3}$ The adsorbent surface which is positively charged in the acidic range will not attract cationic MB molecules. After increasing the $\mathrm{pH}$ from 2 to 7 the surface of ASAC will get negatively charged ions which accumulated the positive MB ions. ${ }^{33}$

\section{Adsorbent Dose and Time Variation}

To investigate the effect of adsorbent dose and running time on the uptake, the operating parameters were taken as dose in the range of $(0.2-0.8 \mathrm{~g} / 100 \mathrm{~mL})$, solution $\mathrm{pH} 7$ and initial MB concentration of $100 \mathrm{mg} / \mathrm{L}$. During the first $150 \mathrm{~min}$ of contact time, the adsorption uptake incenses exponentially but after 240 minutes the change in uptake becomes constant (Fig.-3). This phenomenon is due to various numbers of free adsorptive locations on the ASAC during initial, but after MB adsorption the availability of vacant 
RASĀYAN J. Chem.

Vol. 13 | No. 2 |979 - 990| April - June | 2020

sites decreases which results in low uptake on ASAC. ${ }^{34} \mathrm{MB}$ removal efficiency was changed according to variation ASAC dose. ${ }^{35}$ Form Fig. 4 it is clear that the MB uptake is $10 \mathrm{mg} / \mathrm{g}$ at ASAC dose of $0.8 \mathrm{~g} / 100$ $\mathrm{mL}$ and it becomes $50 \mathrm{mg} / \mathrm{g}$ at a dose of $0.2 \mathrm{~g} / 100 \mathrm{~mL}$. At higher ASAC does the MB uptake is low because a high percentage of ASAC in compression to MB dye and ASAC remains unsaturated. ${ }^{36,21}$ Therefore foe the next experiments the ASAC dose is taken as $0.2 \mathrm{~g} / 100 \mathrm{~mL}$.

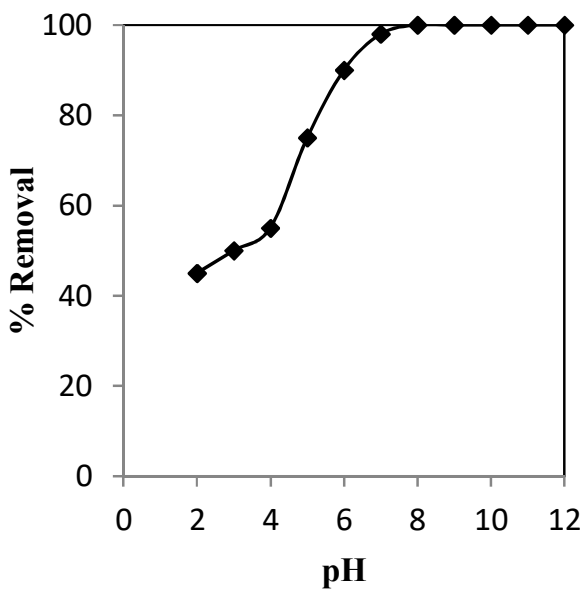

Fig.-3: Effect of Initial pH of Solution on MB Removal (Initial Conc.: $100 \mathrm{mg} / \mathrm{l}$; Contact Time $360 \mathrm{~min}$; Adosrbent Dose $0.25 \mathrm{~g} / 100 \mathrm{ml}$; Agitation Speed: $180 \mathrm{rpm}$; Temp.: $30^{\circ} \mathrm{C}$ )

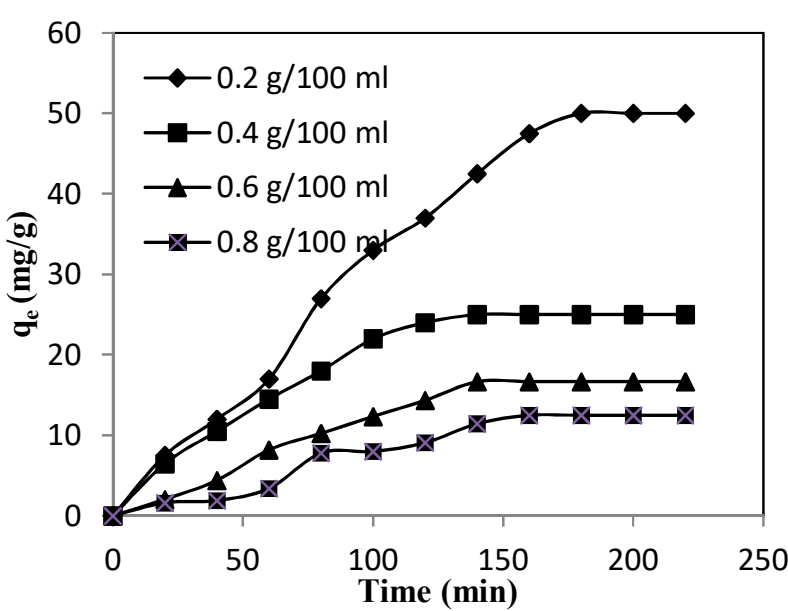

Fig.-4: Effect of Adsorbent Dose Methylene Blue Uptake (Initial Conc.: $100 \mathrm{mg} / \mathrm{L}$; Solution $\mathrm{pH}$ 7; Agitation Speed: $180 \mathrm{rpm}$; Temp.: $30^{\circ} \mathrm{C}$ )

\section{Effect of Initial MB Concentration}

The concentration of MB dye effects the adsorption percentage removal. For this percentage removal and uptake of MB versus initial MB concentration are presented in Fig.-5 for the concentration range of 50 $\mathrm{mg} / \mathrm{L}-800 \mathrm{mg} / \mathrm{L}$. It is carried out from the figure that the removal of MB dye is $100 \%$ up to $100 \mathrm{mg} / \mathrm{L}$, MB concentration and it is decreased reaching $75 \%$ at $800 \mathrm{mg} / \mathrm{L} \mathrm{MB}$ concentration. The $\mathrm{q}_{\mathrm{e}}$ value of by the ASAC increases by increasing MB concentration and it is reached at good adsorption uptake value of $270 \mathrm{mg} / \mathrm{g}$ for $800 \mathrm{mg} / \mathrm{L} \mathrm{MB}$ concentration. The reason for this is the mass transfer resistance which is affected at different MB concentrations by interaction with solid-phase ASAC. At higher concentration of MB increases the interaction of MB molecules on the surface of ASAC which gives a high value of dye uptake. $^{37,38}$ The same type of result has been got by waste rice activated carbon ${ }^{14}$ and nanoporous carbon. ${ }^{39}$

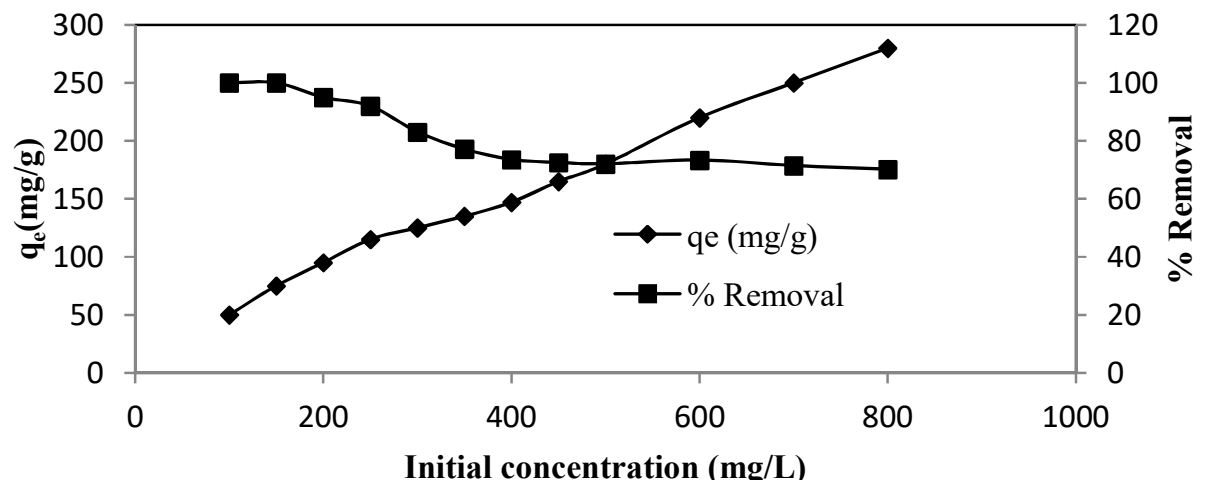

Fig.-5: Effect of Initial MB Concentration (Solution pH: 2; Agitation Speed: $180 \mathrm{rpm}$; Dose: 0.2g/100ml; Temperature $30^{\circ} \mathrm{C}$; Time: $240 \mathrm{~min}$.)

\section{Adsorption Isotherm}

For the determination of the adsorption mechanism, the adsorption isotherm is preferred analysis. This analysis indicates how the liquid phase containing adsorbate molecules is spread on the surface of the 
RASĀYAN J. Chem.

Vol. 13 | No. 2 |979 - 990| April - June | 2020

adsorbent and liquid phase. The values of adsorption isotherm are useful to carry out the suitable isotherm model that may help in design findings. To investigate the best adsorption isotherm model, four models, like the Langmuir, Freundlich, Temkin and Dubinin-Radushkevich were tested in present experiments. The suitable isotherm models were compared by relating the correlation coefficients, $\mathrm{R}^{2}$ in this study.

The Langmuir isotherm assumes monolayer adsorption with all the active sites having equal adsorption capacity and no trans-movement of adsorbate on the surface of the adsorbent. ${ }^{40,41}$ The linear relation of the isotherm is presented as Eq.-2:

$$
\frac{C_{e}}{q_{e}}=\frac{C_{e}}{q_{m}}+\frac{1}{b q_{m}}
$$

Where $q_{m}\left(\mathrm{mg} \mathrm{g}^{-1}\right)$ is the maximum quantity of MB on the unit mass of adsorbent surface to cover the single layer. A significant finding of Langmuir isotherm employed by a dimensionless value, $R_{L}$ which represents the separation factor is evaluated by Eq.-3:

$$
R_{L}=\frac{1}{1+b C_{0}}
$$

Where adsorption equilibrium constant is represented by $b(\mathrm{~L} / \mathrm{mg})$ which responds to the energy of adsorption. The obtained value of $R_{\mathrm{L}}(0<1)$ represents a favorable process of adsorption.

The Freundlich isotherm assumes heterogeneous surface having different adsorption energies at different active sites and adsorption is affected by other adsorbed molecules of adsorbent ${ }^{42,43}$. The liner form of this isotherm is carried out by the following given Eq.-4:

$$
\ln q_{e}=\ln k_{f}+\frac{1}{n} \ln C_{e}
$$

Where constant, $K_{f}\left(\mathrm{mg} \cdot \mathrm{g}^{-1}\left(\mathrm{~L}_{\mathrm{mg}} \mathrm{m}^{-1}\right)^{1 / n}\right)$ indicates the adsorption capacity and $\mathrm{n}$ stands for the intensity of attachment of molecules on the surface of adsorbents. The calculated values for $1 / n$ less than one indicate the favorable adsorption. ${ }^{44}$

Tempkin isotherm model contains a factor that gives the idea about the attraction of adsorbate on the solid surface of the adsorbent. This model predicted that the heat of adsorption of all the adsorbent particles in the layer decreases and it is governed by liner function not by a logarithmic relation. ${ }^{45}$ The nonlinear form of Tempkin model is given by Eq. -5 :

$$
q_{e}=\frac{R T}{b_{t}} \ln \left(A_{T} C_{e}\right)
$$

The linear correlation of Eq.4 can be simplified as given by Eq.-6:

$$
q_{e}=B_{T} \ln A_{T}+B_{T} \ln C_{e}
$$

Where, $B_{T}=(\mathrm{RT}) / b_{T}$, and $\left.\mathrm{R}=8.314 \mathrm{~J} \mathrm{~mol} / \mathrm{K}\right)$ represents a universal gas constant and the absolute temperature is $\mathrm{T}(\mathrm{K})$. The constant $b_{T}$ describes the heat of MB adsorption and $A_{T}$ explains the binding constant $(\mathrm{L} / \mathrm{min})$ which is related to the maximum binding energy. A graph is drawn for $\mathrm{q}_{\mathrm{e}}$ versus $\ln C_{e}$ to calculate the constants, $A_{T}$ and $b_{T}$.

The Dubinin and Radushkevich model which is known as (D-R) model. This model is presented for the determination of the adsorption process whether it is physical or chemical. ${ }^{46,47}$ This model dose not assumes a homogenous surface having constant adsorption capacity and the apparent energy adsorption is calculated by D-R isotherm model. The nonlinear equation of $\mathrm{D}-\mathrm{R}$ isotherm model is explained by following Eq.-7:

$$
q_{e}=q_{m} \exp \left(-\mathrm{K} \varepsilon^{2}\right)
$$

Where the constant $\mathrm{K}$ responds for the adsorption energy in $\mathrm{mol}^{2} / \mathrm{J}^{2}$. The Polanyi potential $(\varepsilon)$ is calculated from the function, RT $\ln (1+(1 / \mathrm{Ce}))$. The mean free energy $(\mathrm{E})$ for adsorption experiments are determined by Eq.-8:

$$
E=\frac{1}{\sqrt{2 K}}
$$


RASĀYAN J. Chem.

Vol. 13 | No. 2 |979 - 990| April - June | 2020

The value $\mathrm{E}$ provides knowledge about the type of adsorption. If the value of $\mathrm{E}$ is less than $8 \mathrm{~kJ} / \mathrm{mol}$ then the adsorption process is governed by physisorption but when the value of $\mathrm{E}$, exceeds to $16 \mathrm{~kJ} / \mathrm{mol}$ then the chemisorptions mechanism occurs for adsorption.
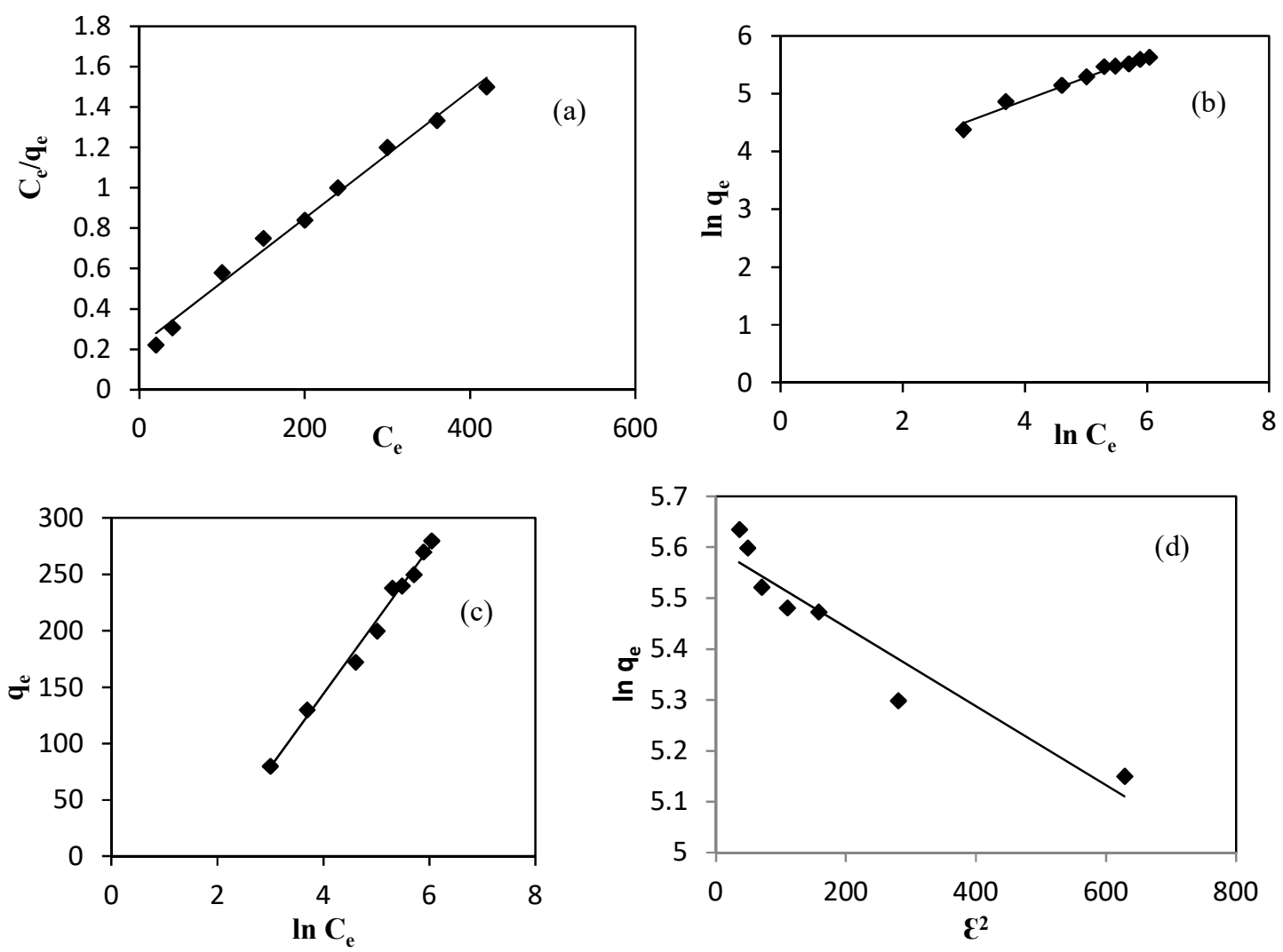

Fig.-6: Adsorption Isotherms for MB Adsorption (a) Langmuir (b) Freundlich (c) Tempkin (d) Dubinin and Radushkevich (Solution pH: 2; Agitation Speed: $180 \mathrm{rpm}$; Dose: 0.2g/100mL; Temperature 30 C; Time: $240 \mathrm{~min}$.)

The adsorption isotherms for all four models are inserted in Fig.- 6 and the calculated results of all the four isotherms are presented in Table-2. The best fit for four isotherms was selected based on the highest correlation coefficient $\left(\mathrm{R}^{2}\right)$ value (closer to 1 ) for the experimentally observed values. Form the graph the value of $\mathrm{R}^{2}$ for the Langmuir model was estimated to 0.998 which was more in compression to other isotherm models. This data confirmed the monolayer adsorption of methylene blue by the Langmuir model on ASAC. The maximum uptake $\left(\mathrm{q}_{\mathrm{m}}\right)$ determined by the Langmuir model is $334.40 \mathrm{mg} / \mathrm{g}$ at temperatures $30{ }^{\circ} \mathrm{C}$ which is related to experimental value and comparable with other activated carbon such as corncob. ${ }^{48}$ The calculated $R_{L}$ values are less than one for concentration ranging $50 \mathrm{mg} / \mathrm{L}$ to 1000 $\mathrm{mg} / \mathrm{L}$ which confirms that the removal of methylene blue is favourable on ASAC. For Freundlich isotherm the constant value, $1 / \mathrm{n}$ is less than unity which refers to the adsorption process is possible but the vale correlation coefficient $\left(\mathrm{R}^{2}=0.974\right)$ is less than as compared to Langmuir isotherm. Table 3 presents the comparison of maximum uptake of MB by different activated carbons.

Tempkin isotherm constant $A_{T}$ and $b_{T}$ are obtained by plotting the curve between $q_{e}$ versus $\ln C_{e}$ and presented in Table-3. The $\mathrm{R}^{2}(0.987)$ value for Temkin isotherm is less in comparison to Langmuir isotherm. The maximum absorption capacity $\mathrm{q}_{\mathrm{m}}$ and $\mathrm{R}^{2}$ values obtained from $\mathrm{D}-\mathrm{R}$ model are $269.88 \mathrm{mgg}^{-1}$ and 0.911. The obtained $\mathrm{q}_{\mathrm{m}}$ and $\mathrm{R}^{2}$ values for $\mathrm{D}-\mathrm{R}$ model are less in comparison to the Langmuir isotherm model (334.40 $\mathrm{mg} \mathrm{g}^{-1}$ and 0.998$)$. The energy of adsorption (E) is observed as $7.071 \mathrm{~kJ} \mathrm{~mol}^{-1}(\mathrm{E}<8.0 \mathrm{~kJ}$ $\left.\mathrm{mol}^{-1}\right)$. This value of E correlates that the adsorption mechanism is followed by physisorption. 
RASĀYAN J. Chem.

Vol. 13 | No. 2 |979 - 990| April - June | 2020

Table- 2: Isotherm Parameters for MB Adsorption on ASAC

\begin{tabular}{c|c|c}
\hline Adsorption Isotherm & Parameters & Values at $30{ }^{\circ} \mathrm{C}$ \\
\hline Langmuir Isotherm & $q_{m}$ & 334.40 \\
\hline & $b$ & 0.0134 \\
\hline & $R^{2}$ & 0.998 \\
\hline Freundlich Isotherm & $R_{L}$ & 0.790 \\
\hline & $K_{f}$ & 27.549 \\
\hline & $n$ & 2.550 \\
\hline Tempkin Isotherm & $R^{2}$ & 0.974 \\
\hline & $A_{T}$ & 0.1686 \\
\hline Dubinin-Radushkevich & $b_{T}$ & 38.79 \\
\hline & $R^{2}$ & 0.987 \\
\hline & $q_{m}$ & 269.88 \\
\hline & $K$ & 0.0001 \\
\hline
\end{tabular}

Table-3: Comparison of MB Adsorption Capacities by Other Activated Carbon with the Present Study

\begin{tabular}{|c|c|c|c|c|}
\hline Adsorbent & $\begin{array}{c}\text { Activating } \\
\text { Agent }\end{array}$ & $\begin{array}{l}\text { BET Surface } \\
\text { Area }\left(\mathrm{m}^{2} / \mathrm{g}\right)\end{array}$ & $\begin{array}{l}\text { Maximum Adsorption } \\
\text { Capacity } \mathrm{q}_{\mathrm{m}}(\mathrm{mg} / \mathrm{g})\end{array}$ & References \\
\hline Pineapple waste & $\mathrm{ZnCl}_{2}$ & 914.67 & 288.34 & [18] \\
\hline Coconut waste & $\mathrm{H}_{2} \mathrm{SO}_{4}$ & - & 149.30 & {$[54]$} \\
\hline Jute fiber & $\mathrm{H}_{3} \mathrm{PO}_{4}$ & - & 225.64 & {$[55]$} \\
\hline Wheat straw & $\mathrm{ZnCl}_{2}$ & 1548 & 555.56 & [39] \\
\hline Cotton & $\mathrm{H}_{3} \mathrm{PO}_{4}$ & 1370 & 476 & {$[56]$} \\
\hline Palm shell & $\mathrm{NaOH}$ & 731.5 & 163 & {$[57]$} \\
\hline Pineapple plant leaves & $\mathrm{H}_{3} \mathrm{PO}_{4}$ & 1031 & 155.50 & {$[58]$} \\
\hline Rice husks & $\mathrm{H}_{3} \mathrm{PO}_{4}$ & 2028.0 & 578.0 & [59] \\
\hline Hazelnut husk & $\mathrm{ZnCl}_{2}$ & 1369.0 & 476.2 & [27] \\
\hline Plomelo skin & $\mathrm{NaOH}$ & 1335.0 & 501.1 & [60] \\
\hline Mangosteen peel waste & $\mathrm{ZnCl}_{2}$ & 1621.8 & 1166 & [61] \\
\hline Corck and paper waste & $\mathrm{NaOH}$ & 1670 & 350 & [62] \\
\hline Banana trunk waste & $\mathrm{H}_{3} \mathrm{PO}_{4}$ & 1173.16 & 199.87 & [63] \\
\hline Sterculia foetida & $\mathrm{H}_{3} \mathrm{PO}_{4}$ & 302.59 & 181.81 & [64] \\
\hline Cashew nut shell & $\mathrm{ZnCl}_{2}$ & 1478.0 & 352 & [65] \\
\hline Sunflower piths & $\mathrm{NaOH}$ & 2690.0 & 965.349 & {$[66]$} \\
\hline Almond shell & $\mathrm{H}_{3} \mathrm{PO}_{4}$ & 1250.0 & 334.40 & Present study \\
\hline
\end{tabular}

\section{Kinetic Study}

For the determination of the kinetics for rate determination of removal, the value of equilibrium data was fitted to different kinetics model. For designing the MB adsorption kinetics, the experiments were performed at various initial concentrations of $\mathrm{MB}$ at $\mathrm{pH} 7$, the temperature of $30^{\circ} \mathrm{C}$, dose of $2.5 \mathrm{~g} / \mathrm{L}$ and running time of $240 \mathrm{~min}$.

\section{Pseudo-First-Order Model}

Lagergren has evaluated a kinetics model that is pseudo-first-order kinetics. ${ }^{49,50}$ The linearized-integral equation for this model is represented as Eq.-9:

$$
\ln \left(q_{e}-q_{t}\right)=\ln q_{e}-k_{1} t
$$

Where $q_{e}$ explained equilibrium uptake in $(\mathrm{mg} / \mathrm{g})$ and $q_{t}(\mathrm{mg} / \mathrm{g})$ adsorption capacity at any time $\mathrm{t}$ $(\mathrm{min})$.The rate contact of this kinetic model, $k_{l}\left(\mathrm{~min}^{-1}\right)$ and adsorption capacity, $q_{e}$ can be investigated from the graph between $\ln \left(q_{e}-q_{t}\right)$ and time $\mathrm{t}(\mathrm{min})$. 
RASĀYAN J. Chem.

Vol. 13 | No. 2 |979 - 990| April - June | 2020

\section{Pseudo-Second-Order Model}

The other kinetic model which is pseudo-second-order is also important for rate contact evaluation ${ }^{51-53}$. The liner form of this model can be expressed as shown in Eq.-10:

$$
\frac{t}{q_{t}}=\frac{1}{k_{2} q_{e}^{2}}+\frac{t}{q_{e}}
$$

Where $k_{2}$ is the rate constant for pseudo-second-order sorption $(\mathrm{g} / \mathrm{mg}-\mathrm{min})$. The rate constant can be calculated by the graph between $t / q_{t}$ and $t$.
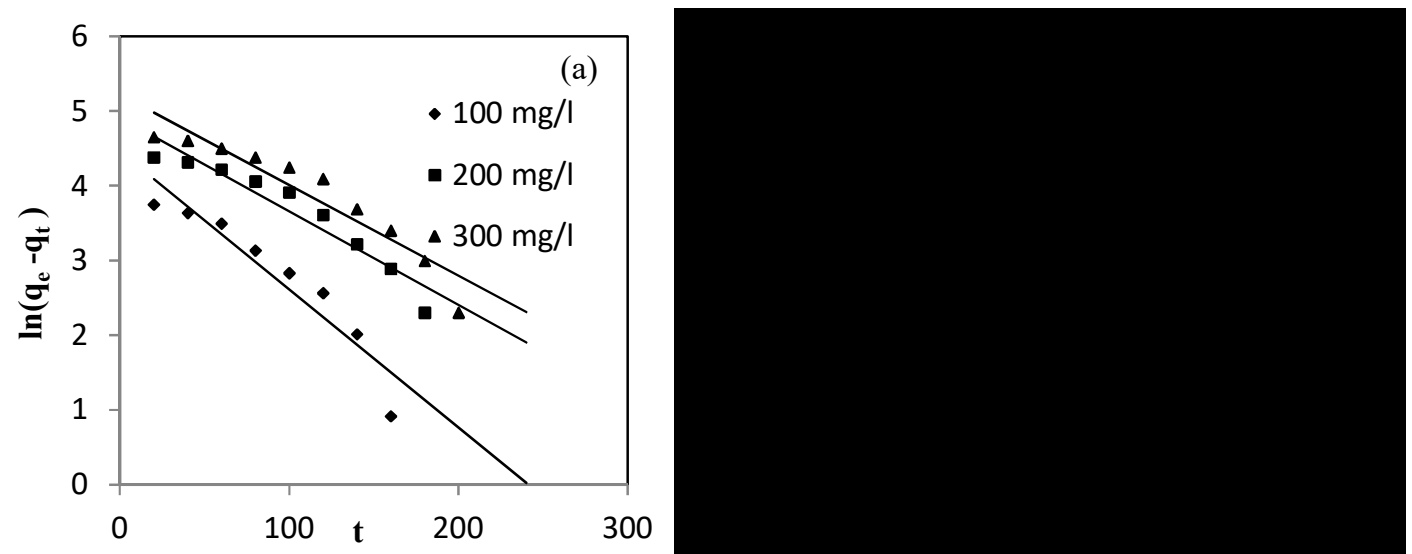

Fig.-7: Adsorption Kinetics Models for MB Adsorption (a) Pseudo First-Order (b) Pseudo Second-Order (Solution pH: 2; Agitation Speed: $180 \mathrm{rpm}$; Dose: $0.2 \mathrm{~g} / 100 \mathrm{~mL}$; Temperature $30^{\circ} \mathrm{C}$; Time: $240 \mathrm{~min}$.; Initial Con. of MB: 100, $200,300 \mathrm{mg} / \mathrm{L})$

The observed data value of different kinetics parameters is tabulated in Table- 4 . The uptake $q_{e}$ and rate constant are explained for both kinetic models. From Fig-7a pseudo first-order model and for pseudo second-order model, Fig.-7b is plotted. The data of correlation coefficients obtained from this linear equation of the pseudo-second-order model are closer to unity $\left(\mathrm{R}^{2}>0.99\right)$ for different initial $\mathrm{MB}$ concentration $(100 \mathrm{mg} / \mathrm{L}-300 \mathrm{mg} / \mathrm{L})$ in compression the pseudo-first-order model $\left(\mathrm{R}^{2}>0.91\right)$ which reveals that the pseudo-second- order model is suitable to design kinetics and rate of adsorption. Also, the calculated value of uptake $\left(\mathrm{q}_{\mathrm{e}}, \mathrm{cal}=138.60 \mathrm{mg} / \mathrm{g}\right)$ is comparable to experimental uptake $\left(\mathrm{q}_{\mathrm{e}}, \exp =130.50\right.$ $\mathrm{mg} / \mathrm{g}$ ) for this model which confirms that second- order kinetic model is responsible for the MB uptake on ASAC.

Table -4: Kinetics Parameters for Adsorption of MB

\begin{tabular}{c|c|c|c}
\hline \multirow{2}{*}{ Kinetic Parameters Models } & \multicolumn{3}{|c}{ Initial Concentration $(\mathrm{mg} / \mathrm{L})$} \\
\cline { 2 - 4 } & 100 & 200 & 300 \\
\hline $\mathrm{q}_{\mathrm{e}}(\mathrm{exp})(\mathrm{mg} / \mathrm{g})$ & 50.0 & 90.70 & 130.50 \\
\hline Pseudo- First- Order Model & & & \\
\hline $\mathrm{k}_{1}$ & 0.018 & 0.012 & 0.013 \\
\hline $\mathrm{q}_{\mathrm{e}}(\mathrm{cal})$ & 86.142 & 135.77 & 185.86 \\
\hline $\mathrm{R}^{2}$ & 0.890 & 0.915 & 0.891 \\
\hline Pseudo -Second -Order Model & & & \\
\hline $\mathrm{k}_{2} \times 10^{-4}$ & 2.43 & 9.5 & 1.13 \\
\hline $\mathrm{q}_{\mathrm{e}}(\mathrm{cal})$ & 66.50 & 110.5 & 138.60 \\
\hline $\mathrm{R}^{2}$ & 0.991 & 0.992 & 0.998 \\
\hline & & &
\end{tabular}

\section{CONCLUSION}

Almond shell wastes were consumed as a precursor material for the preparation of activated carbon which has porous and having high surface area by chemical activation with $\mathrm{H}_{3} \mathrm{PO}_{4}$. The surface area of ASAC by BET method was calculated as $1250 \mathrm{~m}^{2} / \mathrm{g}$ with a different functional group that was responsible for MB uptake. The prepared ASAC was utilized as an economical and easily available adsorbent for removal of $\mathrm{MB}$ dye having high adsorption extent of $334.40 \mathrm{mg} / \mathrm{g}$ at $30{ }^{\circ} \mathrm{C}$ which is more than in 
compression to many other activated carbon. The calculated equilibrium data of MB adsorption onto ASAC were best explained by the Langmuir isotherm model and the MB removal kinetics were evaluated and designed by pseudo-second-order kinetic model.

\section{REFERENCES}

1. O. Anjaneya, S. S. Shrishailnath, K. Guruprasad, A. S. Nayak, S. B. Mashetty, T. B. Karegoudar, International Biodeterioration \& Biodegradation, 79, 64(2013), DOI:10.1016/j.ibiod.2013.01.006

2. P. Kumar, S. Ramalingam, K. Sathishkumar, Korean Journal of Chemical Engineering, 28, 149(2011), DOI:10.1007/s11814-010-0342-0

3. I. A. W. Tan, B. H. Hameed, A. L. Ahmad, Chemical Engineering Journal, 127, 111(2007), DOI: $10.1016 /$ j.cej.2006.09.010

4. W. Chen, F. He, S. Zhang, Environmental Science Pollution Research, 25, 9840(2018), DOI: $10.1007 / \mathrm{s} 1135$

5. M. I. Khan, T. K. Min, K. Azizli , S. Sufian, Z. Man, H. Ullah , RSC Advances, 5, 61410(2015), DOI: $10.1039 / \mathrm{c} 5 \mathrm{ra} 08255 \mathrm{~b}$

6. G. Sharma, A. Kumar, M. Naushad, A. Kumar, A. H. Al-Muhtaseb, P. Dhiman, A. A. Ghfar, F. J. Stadler, M. R. Khan, Journal of Cleaner Production, 172, 2919(2016), DOI: 10.1016/j.jclepro.2017.11.122

7. B. K. Nandi, A. Goswami, M. K. Purkait, Applied Clay Science, 42, 583(2009), DOI: $10.1016 /$ j.clay.2008.03.015

8. J. Acharya, J. N Sahu, C. R. Mohanty, B. C. Meikap, Chemical Engineering Journal, 150, 25(2009), DOI: $10.1016 /$ j.cej.2008.11.035

9. D. Das, D. P. Samal, B. C. Meikap, Journal of Chemical Engineering Process Technology, 6(5), 1(2015), DOI: 10.4172/2157-7048.1000248

10. H. N. Bhatti, A. Jabeen, M. Iqbal, Journal of Molecular Liquid, 237, 322(2017), DOI: 10.1016/j.molliq.2017.04.033

11. J. N. Sahu, J. Acharya, B. C. Meikap, Bioresource Technology, 101, 1974(2010), DOI: 10.1016/j.biortech.2009.10.031

12. S. Chakraborty, S. De, S. D. Gupta, J. K Basu, Chemosphere, 58, 1079(2005), DOI:10.1016/j.chemosphere.2004.09.066

13. K. Y. Foo, B. H Hameed, Chemical Engineering Journal, 173, 385(2011), DOI:10.1016/j.cej.2011.07.073

14. S. Sangon, A. J. Hunt, T. M Attard, P. Mengchang, Y. Ngernyen, N. Supanchaiyamat, Journal of Cleaner Production, 172, 1128 (2018), DOI:10.1016/j.jclepro.2017.10.210

15. S. S Lam, R. K. Liew, Y. M Wong, P. N. Y. Yek, N. L. Ma, C. L. Lee, H. A. Chase, Journal of Cleaner Production,162, 1376(2017), DOI:10.1016/j.jclepro.2017.06.131

16. M. A. Islam, S. Sabar, A. Benhouria, Journal of the Taiwan Institute of Chemical Engineering,74, 96(2017), DOI:10.1016/j.jtice.2017.01.016

17. K. J. Cronje, K. Chetty, M. Carsky, J. N. Sahu, B. C. Meikap, Desalination, 275, 276(2011), DOI: $10.1016 / j . d e s a l .2011 .03 .019$

18. M. N. Mahamad, M. A. A Zaini, Z. A Zakaria, International Biodeterioration \& Biodegradation, 102, 274 (2015), DOI:10.1016/j.ibiod.2015.03.009

19. Y. Miyah, A. Lahrichi, M. Idrissi, Surface and Interfaces, 11, 74(2018), DOI: $10.1016 /$ j.surfin.2018.03.006

20. K. Mohanty, J. T. Naidu, B. C. Meikap, M. N. Biswas, Industrial and Engineering Chemistry Research, 45, 5165(2006), DOI: 10.1021/ie060257r

21. Z. Li, G. Wang, K. Zhai, C. He, Q. Li, P. Guo, Colloids and Surface A: Physicochemical and Engineering Aspects, 538, 28(2018), DOI:10.1016/j.colsurfa.2017.10.046

22. O. Uner, Materials Chemistry and Physics, 237, 121858(2019), DOI: $10.1016 /$ j.matchemphys.2019.121858

23. V. K. Gupta, S. Agarwal, T. Saleh , Journal of Hazardous Materials, 185, 17(2011), DOI: 10.1016/j.jhazmat.2010.08.053 
RASĀYAN J. Chem.

Vol. 13 | No. 2 |979 - 990| April - June | 2020

24. A. Mamanía, N. Ramírezb, C. Deianaa, M. Giméneza, F. Sardella, Journal of Environmental Chemical Engineering, 7, 1031(2019), DOI: 10.1016/j.jece.2019.103148

25. Q. Xu, Q. Qian, A. Quek, N. Ai, G. Zeng, J. Wang, ACS Sustainable Chemistry and Engineering ,1, 1092 (2013), DOI: 10.1021/sc400118f

26. Y. Zhang, X. Song, Y. Xu ,H. Shen, X. Kong, H. Xu, Journal of cleaner production, 210, 366(2019), DOI:10.1016/j.jclepro.2018.11.041

27. G. Karaçetin, S. Sivrikaya, M. Imamoglu, Journal of Analytical and Applied Pyrolysis, 110, 270(2014), DOI:10.1016/j.jaap.2014.09.006

28. Y. Onal, A. C. Basar, S. C. Ozdemir, S. Erdogan, Journal of Hazardous Materials, 142, 138 (2007), DOI:10.1016/j.jhazmat.2006.07.070

29. G. Pari, S. Darmawan, B. Prihandoko, Procedia Environmental Science, 20, 342(2014), DOI:10.1016/j.proenv.2014.03.043

30. M. E. Fernandez, B. Ledesma, S. Román, P.R. Bonelli, A. L. Cukierman, Bioresource Technology, 183, 221(2015), DOI: 10.1016/j.biortech.2015.02.035

31. B. H. Hameed, A.L Ahmad, K.N.A Latiff, Dyes and Pigment, 75, 143(2007), DOI:10.1016/j.dyepig.2006.05.039

32. A. M. Aljeboree, A. F. Alkaim, A. H. Al-Dujaili, Desalination and Water Treatment, 53, 3656(2015), DOI:10.1080/19443994.2013.877854

33. E. A. Khan , Shahjahan, T. A. Khan, Journal of Molecular Liquid, 249, 1195(2018), DOI:10.1016/j.molliq.2017.11.125

34. D. Pathania, S. Sharma, P. Singh, Arabian Journal of Chemistry, 10, S1445(2017), DOI: 10.1016/j.arabjc.2013.04.021

35. S. Naeem, V. Baheti, J. Wiener, J. Marek, Journal of Textile Institute, 108, 803(2017), DOI: 10.1080/00405000.2016.1191745

36. Y. Bulut, H. Aydin, Desalination, 194, 259(2006), DOI:10.1016/j.desal.2005.10.032

37. D. K. Mahmoud, M. A. M. Salleh, W. A. W. A. Karim, Chemical Engineering Journal, 181-182, 449(2012), DOI:10.1016/j.cej.2011.11.116

38. M. A. Islam, I. A. W. Tan, A. Benhouria, M. Asif, B. H. Hameed, Chemical Engineering Journal, 270, 187(2015), DOI: $10.1016 /$ j.cej.2015.01.058

39. X. Han, H. Wang, L. Zhang, Water Air and Soil Pollution, 229, 26(2018), DOI:10.1007/s11270-017$3682-0$

40. I. Langmuir, Journal of American Chemical Society, 40, 1361(1918), DOI:10.1021/ja02242a004

41. J. R. García, U. Sedran, M. A. A. Zaini, Environmental Science and Pollution Research, 25, 5076(2018), DOI:10.1007/s11356-017-8975-8

42. H. M. F. Freundlich, Journal of Physics and Chemistry, 57A, 385(1906), DOI:10.1515/zpch-19075723

43. A. Rahman, H. J. Hango, L. S. Daniel, V. Uahengo, S. J. Jaime, S. Bhaskaruni, S. B. Jonnalagadda, Journal of Cleaner Production, 237, 117689(2019), DOI:10.1016/j.jclepro.2019.117689

44. A. Khasri , M. A. Ahmad, Environmental Science and Pollution Research, 25, 31508(2018), DOI: 10.1007/s11356-018-3046-

45. S. Rani, M. Bansal, K. Kaur, S. Sharma, Rasayan Journal of Chemistry, 12(3), 1247,(2019), DOI: 10.31788/RJC.2019.1235171

46. S. Rengaraj, Y. Kim, C. K. Joo, K. Choi, J. Yi, Korean Journal of Chemical Engineering, 21, 187(2004), DOI: 10.1007/BF02705397

47. N. Saibaba KV, R. V. Kandisa, Rasayan Journal of Chemistry, 12(4), 2176(2019), DOI: 10.31788/RJC.2019.1245478

48. H. Ma, J. B. Li, W.W. Liu, M. Miao, B. J. Cheng, S.W. Zhu, Bioresource Technology, 190, 13(2015), DOI:10.1016/j.biortech.2015.04.048

49. J. Kanjanarong, B. S. Giri, D. P. Jaisi , F. R. Oliveira, P. Boonsawang, S. K Khanal, Bioresource Technology, 234, 115(2017), DOI: 10.1016/j.biortech.2017.03.009

50. W. Huang, J. Chen, J. Zhang, Environmental Science and Pollution Research, 25, 29256 (2018), DOI: $10.1007 / \mathrm{s} 11356-018-2906-1$ 
RASĀYAN J. Chem.

Vol. 13 | No. 2 |979 - 990| April - June | 2020

51. A. Mittal , A. Mittal, J. Malviya, D. Kaur, V. K. Gupta, Journal of Colloid and Interface Science, 342, 518(2010), DOI: $10.1016 /$ j.jcis.2009.10.046

52. M. K. Rai, G. Shahi, V. Meena, R. Meena, S. Chakraborty, R. S. Singh , B. N. Rai, Resource Efficient Technolology, 2, 63(2016), DOI: 10.1016/j.reffit.2016.11.011

53. M. Ravikumar, P. King, Rasayan Journal of Chemistry, 12(4), 2318(2019), DOI: $10.31788 /$ RJC.2019.1244034

54. A. H. Jawad, R. A. Rashid, M. A. M. Ishak, L. D. Wilson, Desalination and Water Treatment, 57, 25194(2016), DOI: 10.1080/19443994.2016.1144534

55. S. Senthilkumaar, P. R. Varadarajan, K. Porkodi, C. V. Subbhuraam, Journal of Colloid and Interface Science, 284, 78(2005), DOI:10.1016/j.jcis.2004.09.027

56. X. Duan, C. Srinivasakannan, X. Wang, F. Wang, X. Liu, Journal of Taiwan Institute of Chemical Engineering ,70, 374(2017), DOI: 10.1016/j.jtice.2016.10.036

57. K. T. Wong, N. C. Eu, S. Ibrahim, H. Kim, Y. Yoon, M. Jang, Journal of Cleaner Production, 115, 337(2016), DOI: 10.1016/j.jclepro.2015.12.063

58. K. K. Beltrame, A. L. Cazetta, P. S. C. de Souza, L. Spessato, T. L Silva, V. C. Almeida Ecotoxicology and Environmental Safety, 147, 64(2018), DOI: 10.1016/j.ecoenv.2017.08.034

59. Y. Chen, S. R. Zhai, N. Liu, Y. Song, Q. D. An, X. W. Song, Bioresource Technology, 144, 401(2013), DOI: 10.1016/j.biortech.2013.07.002

60. K.Y. Foo, Process Safety and Environmental Protection, 116, 461(2018), DOI: $10.1016 /$ j.psep.2018.01.022

61. A. Nasrullah, B. Saad, A. Bhat, A. S. Khan, M. Danish, M. H. Isa, A. Naeem, Journal of Cleaner Production, 211, 1190(2019), DOI:10.1016/j.jclepro.2018.11.094

62. R. M. Novais, A. P. Caetano, M. P. Seabra, J. A. Labrincha, R. C. Pullar, Journal of cleaner production, 197, 1137 (2018), DOI:10.1016/j.jclepro.2018.06.278

63. M. Danish, T. Ahmad, S. Majeed, M. Ahmad, L. Ziyang, Z. Pin, S.S. Iqubal, Bioresource Technology Reports, 3, 127(2018), DOI: 10.1016/j.biteb.2018.07.007

64. S. Basu, G. Ghosh, S. Saha, Process Safety and Environmental Protection, 117, 125(2018), DOI:10.1016/j.psep.2018.04.015

65. A. A. Spagnoli, D. A. Giannakoudakis, S. Bashkova, Journal of Molecular Liquids, 229, 465(2017), DOI: 10.1016/j.molliq.2016.12.106

66. M. Baysal, K. Bilge, B. Yılmaz, M. Papila, Y. Yürüm, Journal of Environmental Chemical Engineering, 6(2), 1702(2018), DOI: 10.1016/j.jece.2018.02.020

[RJC-5627/2019] 